\title{
The implementation of a new ISO 22000 in the Cyprus olive oil industry
}

\author{
A. A. Zorpas ${ }^{1} \&$ N. Tzia ${ }^{2}$

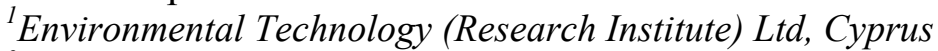 \\ ${ }^{2}$ Laboratory of Food Chemistry and Technology, \\ School of Chemical Engineering, \\ National Technical University of Athens, Greece
}

\begin{abstract}
Quality and safety are important for the delicatessen industries. The quality assurance of the whole process is significant for consumer acceptability, while the assurance of safety is obligatory for the protection of public health. Quality is required in order for the product to meet the customers' specifications and may be assured by application of a quality management system such as ISO 9001. As far as food safety is concerned, E.C. food legislation, recognizing the significance of the safety for human health, has established the application of $852 / 2004$ in which the basic hygiene and HACCP requirements are defined. Implementation of the HACCP system is a fundamental approach to ensure the safety of the food supply, providing a systematic procedure for the identification, evaluation and control of hazards in each operation. Risk profiling is one activity in preliminary risk management that has recently been defined as a description of a food safety problem and its context developed for the purpose of identifying those elements of a hazard or risk that are relevant to risk management decisions. In Cyprus food plants have started to apply safety programs in the past few years in a preliminary way to comply with the food safety legislation and regulations $(852 / 2004 / \mathrm{EU}, 854 / 2004 / \mathrm{EU})$. This paper describes the application of the above according to the new standard ISO 22000:2005 in an olive oil (olive oil production line) industry in Cyprus.
\end{abstract}

Keywords: ISO 22000, food safety, quality assurance, olive oil. 


\section{Introduction}

Food hygiene is defined by Codex Alimentarius as 'all conditions and measures necessary to ensure the safety and suitability of food in all stages of food chain' [1]. The HACCP (hazard analysis critical control point) system is compulsory in EU member states for safety assurance based on hazard analysis while prerequisite hygiene programs (GHPs: Good Hygiene Practices, GMPs: Good Manufacturing Practices) are necessary to support the system [2]. Methods to conduct a hazard analysis [3] and establish critical control points using risk assessment and food borne outbreak evaluations [4] have more recently been supported by elaboration of the risk profiling approach. HACCP is a highly specialized system for food safety that is needed for carrying out an analytical study of microbiological, chemical and physical hazards. Hazard analysis contains the identifications of potential hazards throughout the food process and the identification of critical stages (CCPs) that must be controlled in order to assure the food safety $[2,5,6]$. Quality and safety are important for the delicatessen industries. The quality assurance of the whole process is significant for consumer acceptability, while the assurance of the safety is obligatory for the protection of public health. Quality is required in order for the product to meet the customers' specifications and may be assured by the application of a quality management system such as ISO 9001. As far as food safety is concerned, E.C. food legislation, recognizing the significance of the safety for human health, has established the application of 852/2004 \& 93/43 in which the basic hygiene and HACCP requirements are defined. Implementation of the HACCP system is a fundamental approach to ensure the safety of the food supply, providing a systematic procedure for the identification, evaluation and control of hazards in each operation. Small business may lack the in house knowledge and resources for the correct implement of HACCP. Before implanting a HACCP system, a food business should already have in place various practices that may be collectively termed prerequisite programs (PRPs) (e.g. raw materials specifications, staff training, hygienically designed facilities and good hygienic practice (GHP) [8].

Risk profiling is one activity in preliminary risk management that has recently been defined as a description of a food safety problem and its context developed for the purpose of identifying those elements of a hazard or risk that are relevant to risk management decisions [9]. Risk profiling involves the systematic collection of information needed to make a decision on what will be done next and which resources should be allocated to more detailed scientific assessment. The risk profiling process typically provides information on: the hazard, exposure to the hazard, adverse health effects, public health surveillance information, control measures, and other information relevant to risk management decision-making.

According to the HACCP principles, in each stage of the food process, all possible hazards (physical, chemical, microbiological) are identified, their importance is evaluated and all the preventive measures for their control are described (principle 1). The Critical Control Point (CCPs) should be identified 
using a risk assessment according to ISO 22000:2005 where control is critical for controlling the safety of the product (principle 2). For each identified CCP critical limits for preventing measures (principle 3) and monitoring systems (principle 4) are established. When monitoring shows that a critical limit has not been met, corrective actions must be taken (principle 5). Finally, procedures to verify that the system is working properly (principle 6) and effective records to document the HACCP system are established (principle 7), [2,5].

In Cyprus there are more than 30 olive oil industries that are produced olive oil. In Cyprus foods plants have started to apply safety programs in the past few years in a preliminary way to comply with the food safety legislation and regulations $(852 / 2004 / \mathrm{EU}, 854 / 2004 / \mathrm{EU})$. The verification activities in plants encompass sampling for monitoring CCPs and determination of microbiological parameters, GHPs-GMPs measurements, review of records, flow diagrams and the HACCP plan amongst others. However, for the implementation of such a safety assurance system, hygienic programs like GHPs-GMPs are also required.

\section{Material and methods}

Olive oil is produced following the general flow diagram (Figure 1). This represents the typical production of a delicatessen based on both the bibliography (Metaxopoulos et al [11]) and the suggestions of the industry's expertise. The processing steps differentiate depending on the product.

In each stage of the process, the first two principles are developed. Thus all possible hazards (physical, chemical, microbiological) are identified, and the preventive measures are described and the CCPs are identified using a risk assessment according to ISO 22000:2005 (Tables 1-3). In particular, a risk assessment by risk levels taking in account both the possibility of appearance and the severity of the danger is used. Following this, as the rest of the principles require, for each identified $\mathrm{CCP}$ critical limits for preventing measures and monitoring systems are proposed, as well as corrective actions. Based on these data, procedures to verify and effective records to document the HACCP system can be established. Also, the prerequisites measures related to GMPs - GHPs in each production step are described.

\section{Results and discussion}

Olive oil is very common to the culture of Cyprus and to Mediterranean recipes (especially in Cyprus, Greece, and Italy). The identification of CCPs and the required actions for their control are crucial for the appropriate HACCP development. However, nowadays risk assessment and the quantification of hazards are recommended focusing on the consumer's health and a higher safety level is proposed. In order to identify the CCPs the methods used are presented in Tables $1-4$. Table 1 presents the possibility of the appearance of a negative impact on public health (SEVERITY-S) using grades $0-3$. Table 2 presents the possibility of the appearance of the specific danger (PROAPILITY-P) using grades $0-2$. Table 3 presents the Risk Level where the Risk Level $=\mathrm{R}=\mathrm{S}+\mathrm{P}$, 
using scale 0-2 for probability and scale 0-3 for the severity. Table 4 presents the Definitions of Risk Level using levels 0-5. Table 5 presents the risk assessment result of the flow chart (figure 1).

According to ISO 22000:2005 all food safety hazards that are reasonably expected to occur in relation to the type of product, type of process and actual processing facilities should be identified and recorded. The identification based:

Table 1: The possibility of the appearance of negative impact on public health (SEVERITY-S).

\begin{tabular}{|c|l|}
\hline Grade & Definition \\
\hline 0 & No damage or human ill. No legal requirement. \\
\hline 1 & $\begin{array}{l}\text { Low concentration of microbiology activities in the food, } \\
\text { which is under the limits. No serious illness of the consumer. } \\
\text { No legal requirement. All the parameters, microbiological } \\
\text { and chemical, are under the limits of all the directives or } \\
\text { legislations. The physical danger can be controlled. }\end{array}$ \\
\hline 2 & $\begin{array}{l}\text { The product can be characterised as degrading (high } \\
\text { concentration of microorganisms and the product is of low } \\
\text { quality). If the product proceeds to the consumer it may } \\
\text { affect a selected population among adults and children. Risk } \\
\text { of mild food poison. The product is better removed from the } \\
\text { market. May have a legal claim. }\end{array}$ \\
\hline 3 & $\begin{array}{l}\text { The product is not acceptable. All the parameters are over the } \\
\text { limits. If the product is ingested the consumer may be in } \\
\text { danger. We have a serious food poisoning risk. We have a } \\
\text { legal claim. The product must be removed immediately from } \\
\text { the market. }\end{array}$ \\
\hline
\end{tabular}

Table 2: The possibility of the appearance of the specific danger (PROAPILITY -P).

\begin{tabular}{|c|l|}
\hline Grade & Definition \\
\hline 0 & Low possibility of appearance \\
\hline 1 & Possible appearance \\
\hline 2 & High possibility of appearance \\
\hline
\end{tabular}

Table 3: $\quad$ Risk level estimator [RISK $=$ SEVERITY + PROBALITY].

\begin{tabular}{|c|c|c|c|c|}
\hline \multirow{2}{*}{ Probability } & \multicolumn{4}{|c|}{ Severity } \\
\cline { 2 - 5 } & 0 & 1 & 2 & 3 \\
\hline 0 & 0 & 1 & 2 & 3 \\
\hline 1 & 1 & 2 & 3 & 4 \\
\hline 2 & 2 & 3 & 4 & 5 \\
\hline
\end{tabular}


Table 4: $\quad$ Definitions of risk level.

\begin{tabular}{|c|c|c|}
\hline $\begin{array}{l}\text { Risk } \\
\text { Level }\end{array}$ & Definition & Required control action \\
\hline 0 & Uncreated & Very low danger. Typical preventative actions. \\
\hline 1 & Very Low & $\begin{array}{l}\text { The danger is accepted by the company and is } \\
\text { under the limits of legislation. The acknowledged } \\
\text { danger appears to be problematic only in selected } \\
\text { members of the population (such as a person with a } \\
\text { heart problem or diabetes). }\end{array}$ \\
\hline 2 & Low & $\begin{array}{l}\text { Danger that requires more checks and control (an } \\
\text { optical check is accepted). The acknowledged } \\
\text { danger appears to be problematic only in selected } \\
\text { members of the population. The HACCP plan may } \\
\text { needs changes. If the corrective actions are repeated } \\
\text { more than } 30 \% \text { in the same procedure and in the } \\
\text { same year then there must be a CCP. All the } \\
\text { parameters are under the limits and the product is } \\
\text { safe. }\end{array}$ \\
\hline 3 & Fair & $\begin{array}{l}\text { Danger that is not acceptable. However the } \\
\text { uncontrolled danger does not show any problems to } \\
\text { public health. It shows problems only in selective } \\
\text { people (such as a person with a heart problem or } \\
\text { diabetes). Also, the product can characterised as } \\
\text { degrading. If the corrective actions are repeated } \\
\text { more than } 10 \% \text { in the same year then it must be a } \\
\text { CCP. The HACCP plan must be re-checked. The } \\
\text { product needs laboratory checks and then proceeds } \\
\text { with corrective actions in order that the procedures } \\
\text { return to safe limits. There is a possibility of having } \\
\text { food poisoning (with transiently symptoms). If the } \\
\text { product is in the market it must be traced back. }\end{array}$ \\
\hline 4 & High & $\begin{array}{l}\text { This is a CCP. The danger is not acceptable and if it } \\
\text { is outside of the limits will cause problems to the } \\
\text { consumer. The product can be characterised as } \\
\text { degrading to dangerous for human health. If the } \\
\text { corrective actions are repeated more than } 5 \% \text { in the } \\
\text { same point or procedure in the total corrective } \\
\text { actions in the same year then it must be a CCP. The } \\
\text { HACCP plan must be re-checked. The product } \\
\text { needs laboratory checks and then proceeds with } \\
\text { corrective actions in order that the procedures are } \\
\text { returned in safe limits. The HACCP Team must be } \\
\text { notified and then all the procedures must be } \\
\text { stopped. Corrective actions must be taken while the } \\
\text { product must be removed from the market. }\end{array}$ \\
\hline
\end{tabular}


Table 4: $\quad$ Continued.

\begin{tabular}{|l|l|l|}
\hline 5 & Very High & $\begin{array}{l}\text { CCP. The entire recognized dangers are not } \\
\text { acceptable. The product is characterised as } \\
\text { unacceptable and very dangerous if it is out of } \\
\text { limits. Significant problems for human health. If the } \\
\text { corrective actions are repeated more than 5\% in the } \\
\text { same year then it must be a CCP. The HACCP plan } \\
\text { must be re-checked. The product needs laboratory } \\
\text { checks and then proceeds with corrective actions in } \\
\text { order that the procedures are returned to safe limits. } \\
\text { The HACCP team must be notified and then all the } \\
\text { procedures must be stopped. The HACCP team } \\
\text { must take corrective action while the product must } \\
\text { be removed immediately from the market. }\end{array}$ \\
\hline
\end{tabular}

\section{$\checkmark$ On experience}

$\checkmark$ On external information from, to the extent possible, epidemiological and other historical data

$\checkmark$ On the preliminary information data collected according to the food safety team, the product characteristics (biological, chemical, physical), methods of production, storage conditions and shelf life, preparation and/or handling before being processed, packaging and delivery methods

Hazard assessment shall be conducted to determine each food safety hazard identified whether its elimination or reduction to acceptable levels is essential to the production of a safe food, and whether its control is needed to enable the defined acceptable levels to be met. Each food safety hazard shall be evaluated according to the possible severity of adverse health effects and the likelihood of their occurrence.

\subsection{Safety analysis results - control of CCPs}

The results of the analysis for the quality and safety hazards of the delicatessen industry are presented in Table 6 . The Table should be used as complementary to the following results. Incoming materials and especially raw meat used in large quantities is a sensitive food as it may support the growth of microbes. For this reason the raw materials delivery is characterised as a Critical Control Point (CCP 1) and should be examined upon each receipt. Certified suppliers and rigorous criteria for raw materials, additives with low microbial counts and the absence of pathogens could greatly contribute to the hygiene quality and safety of the final product. Food handling errors, inadequate storage practices and improper holding temperatures may also occur [10]. 
Table 5: Risk assessment result (M: microbiological, $\mathrm{C}$ : chemical, $\mathrm{P}$ : physical dangerous).

\begin{tabular}{|c|c|c|c|c|c|}
\hline $\begin{array}{l}\text { Stage of the } \\
\text { flow chat } \\
\text { (Fig. } 1)\end{array}$ & Danger & $\begin{array}{l}\text { Severity } \\
\text { (S) }\end{array}$ & $\begin{array}{l}\text { Probability } \\
\text { (P) }\end{array}$ & Risk $=\mathrm{S}+\mathrm{P}$ & $\begin{array}{l}\text { Category } \\
\text { CCP/GMP }\end{array}$ \\
\hline \multirow{3}{*}{$\begin{array}{c}\text { Receipt/storage } \\
\text { of olives }\end{array}$} & $\mathrm{M}$ & 1 & 2 & 3 & GMP \\
\hline & $\mathrm{C}$ & 1 & 2 & 3 & GMP \\
\hline & $\mathrm{P}$ & 1 & 2 & 3 & GMP \\
\hline \multirow{3}{*}{$\begin{array}{l}\text { Transfer of the } \\
\text { olives to the } \\
\text { leaf remover }\end{array}$} & $\mathrm{M}$ & 2 & 1 & 3 & GMP \\
\hline & $\mathrm{C}$ & 2 & 1 & 3 & GMP \\
\hline & $\mathrm{P}$ & 1 & 1 & 2 & GMP \\
\hline \multirow{3}{*}{$\begin{array}{c}\text { Washing of } \\
\text { olives }\end{array}$} & $\mathrm{M}$ & 2 & 1 & 3 & GMP \\
\hline & $\mathrm{C}$ & 1 & 1 & 2 & GMP \\
\hline & $\mathrm{P}$ & 2 & 2 & 4 & CCP 1 \\
\hline \multirow{3}{*}{$\begin{array}{l}\text { Breaking of the } \\
\text { fruit }\end{array}$} & $\mathrm{M}$ & 2 & 1 & 3 & GMP \\
\hline & $\mathrm{C}$ & 2 & 1 & 3 & GMP \\
\hline & $\mathrm{P}$ & 1 & 2 & 3 & GMP \\
\hline \multirow{3}{*}{$\begin{array}{l}\text { Milling of the } \\
\text { fruit }\end{array}$} & $\mathrm{M}$ & 2 & 1 & 3 & GMP \\
\hline & $\mathrm{C}$ & 1 & 1 & 2 & GMP \\
\hline & $\mathrm{P}$ & 1 & 1 & 2 & GMP \\
\hline \multirow{3}{*}{$\begin{array}{l}\text { Kneading of the } \\
\text { fruit }\end{array}$} & $\mathrm{M}$ & 2 & 2 & 4 & CCP 2 \\
\hline & $\mathrm{C}$ & 2 & 2 & 4 & CCP2 \\
\hline & $\mathrm{P}$ & 1 & 1 & 2 & GMP \\
\hline \multirow{3}{*}{$\begin{array}{l}\text { The olive paste } \\
\text { goes to the } \\
\text { centrifuge }\end{array}$} & $\mathrm{M}$ & 1 & 1 & 2 & GMP \\
\hline & $\mathrm{C}$ & 1 & 1 & 2 & GMP \\
\hline & $\mathrm{P}$ & 1 & 1 & 2 & GMP \\
\hline \multirow{3}{*}{$\begin{array}{l}\text { Filtration of the } \\
\text { olive oil }\end{array}$} & $\mathrm{M}$ & 1 & 2 & 3 & GMP \\
\hline & $\mathrm{C}$ & 1 & 1 & 2 & GMP \\
\hline & $\mathrm{P}$ & 2 & 2 & 4 & CCP 3 \\
\hline \multirow{3}{*}{$\begin{array}{l}\text { Final filtration } \\
\text { of the olive oil }\end{array}$} & $\mathrm{M}$ & 1 & 1 & 2 & GMP \\
\hline & $\mathrm{C}$ & 1 & 1 & 2 & GMP \\
\hline & $\mathrm{P}$ & 1 & 2 & 3 & GMP \\
\hline \multirow{3}{*}{$\begin{array}{l}\text { Place the olive } \\
\text { oil into the } \\
\text { clients' pots }\end{array}$} & $\mathrm{M}$ & 2 & 1 & 3 & GMP \\
\hline & $\mathrm{C}$ & 1 & 1 & 2 & GMP \\
\hline & $\mathrm{P}$ & 2 & 1 & 3 & GMP \\
\hline \multirow{3}{*}{ Storage } & $\mathrm{M}$ & 2 & 1 & 3 & GMP \\
\hline & $\mathrm{C}$ & 1 & 0 & 1 & GMP \\
\hline & $\mathrm{P}$ & 1 & 1 & 2 & GMP \\
\hline \multirow{3}{*}{$\begin{array}{l}\text { Receive from } \\
\text { the client }\end{array}$} & $\mathrm{M}$ & 1 & 1 & 2 & GMP \\
\hline & $\mathrm{C}$ & 1 & 0 & 1 & GMP \\
\hline & $\mathrm{P}$ & 1 & 1 & 2 & GMP \\
\hline
\end{tabular}




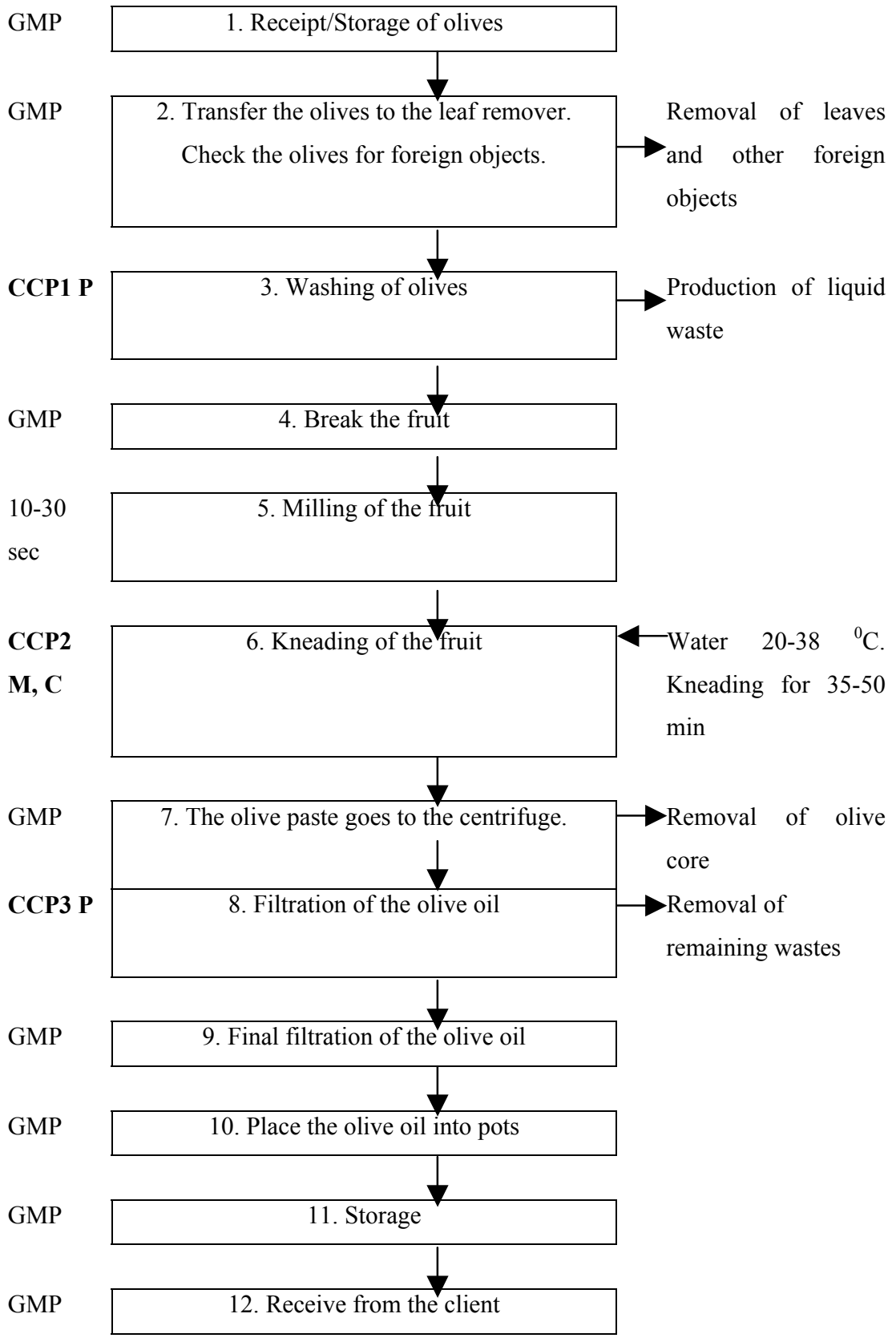

Figure 1: Olive oil production flow chat. 


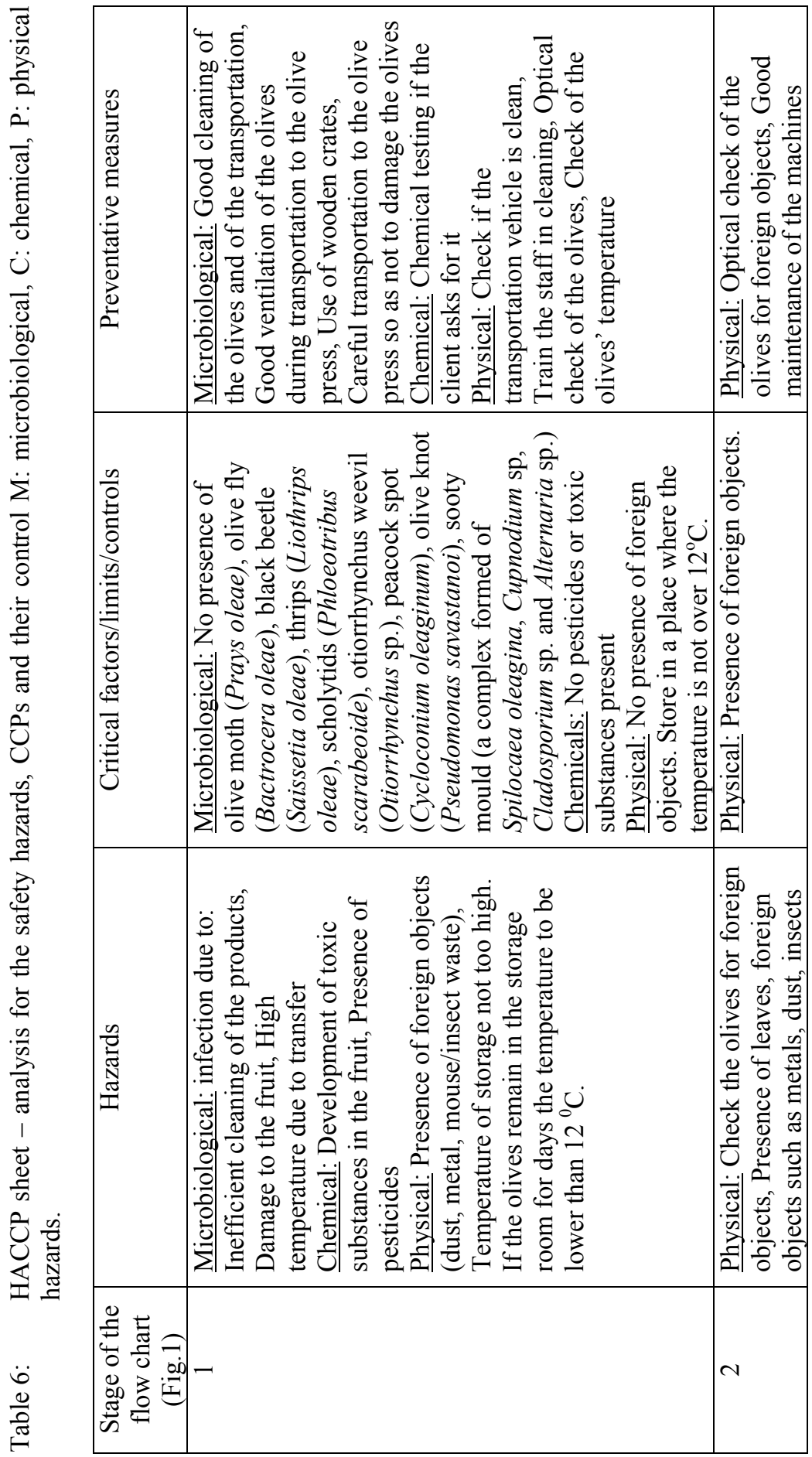

WIT Transactions on Information and Communication, Vol 39, (C) 2008 WIT Press www.witpress.com, ISSN 1743-3517 (on-line) 


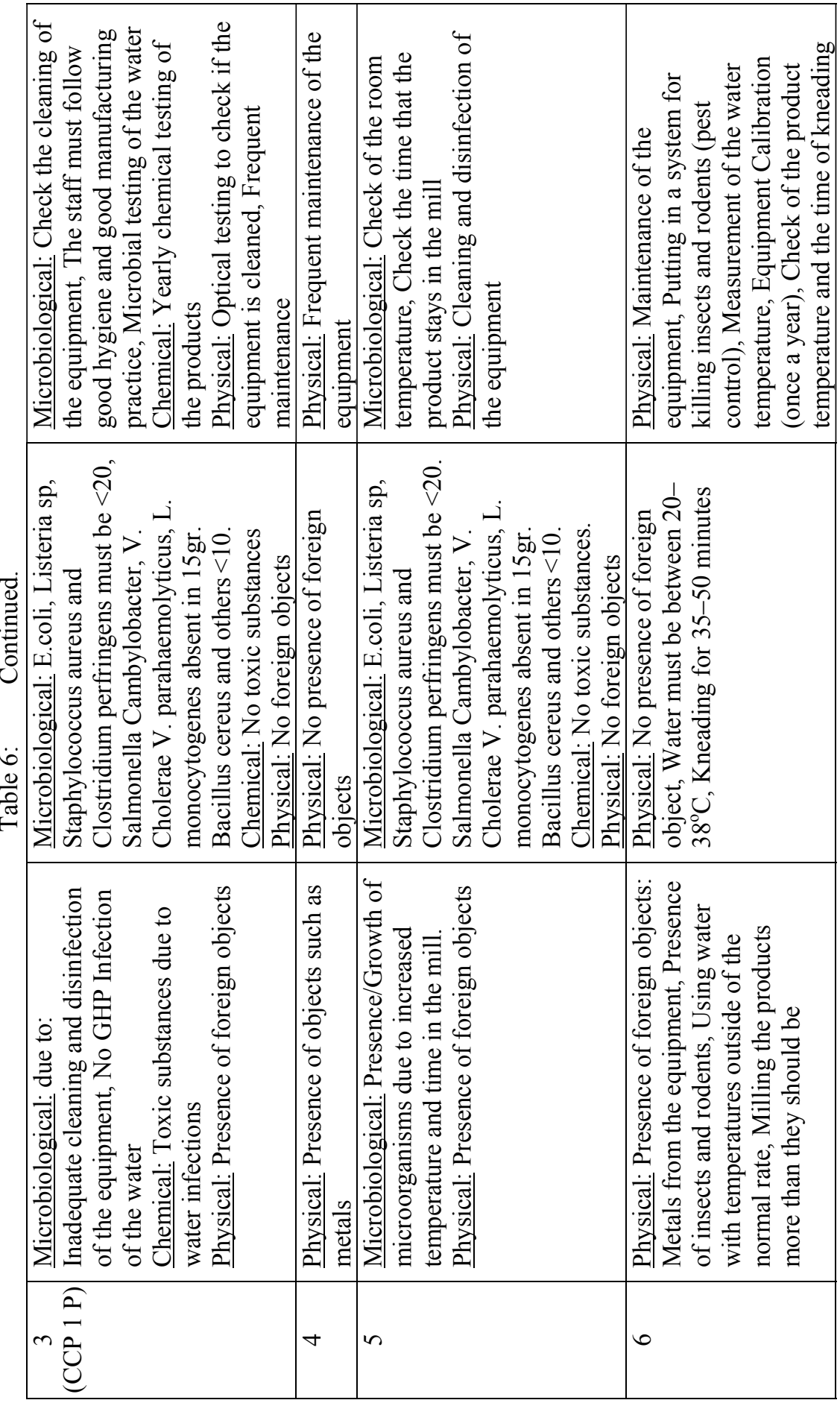

WIT Transactions on Information and Communication, Vol 39, (C) 2008 WIT Press www.witpress.com, ISSN 1743-3517 (on-line) 


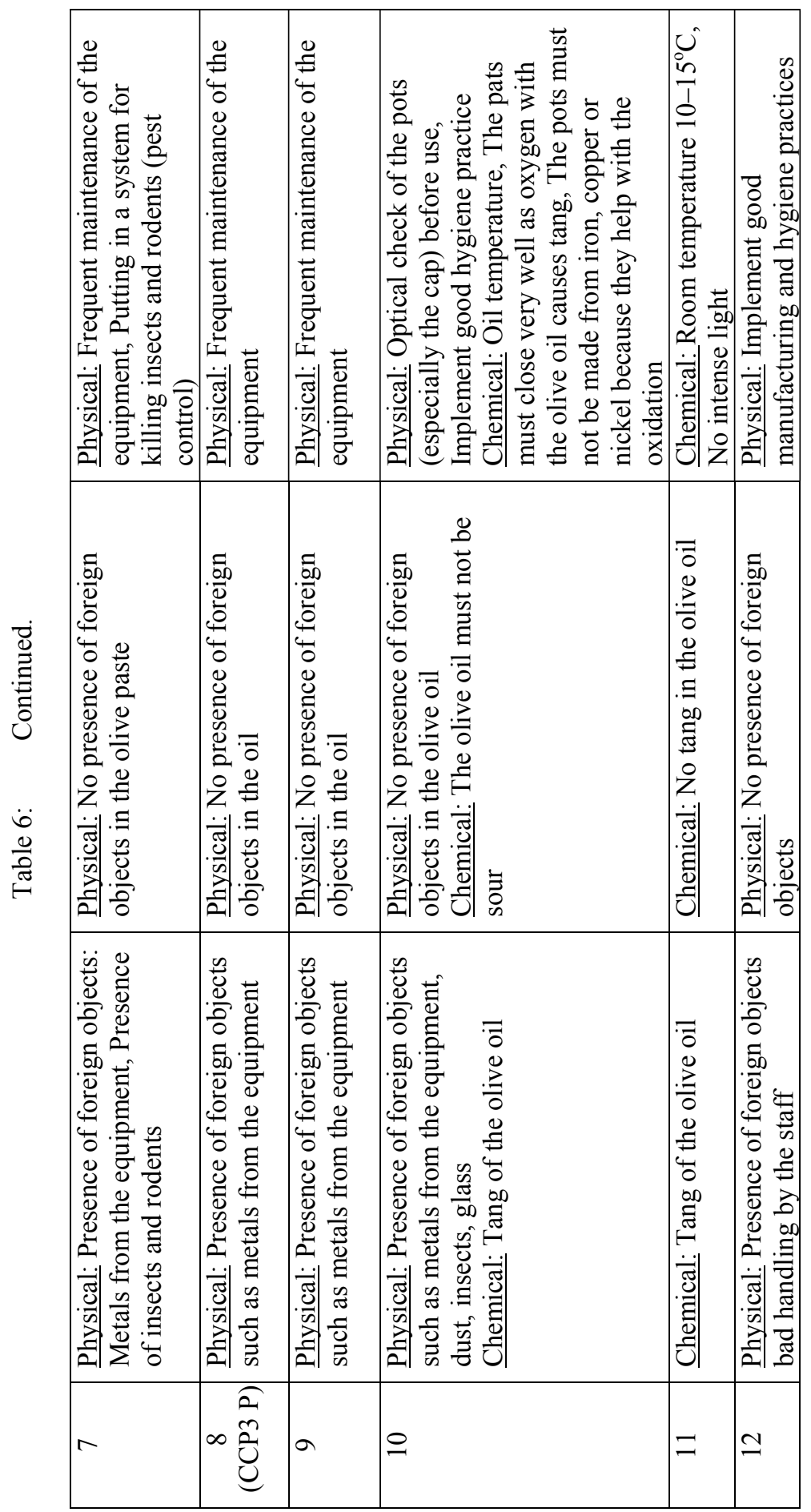

WIT Transactions on Information and Communication, Vol 39, (C) 2008 WIT Press www.witpress.com, ISSN 1743-3517 (on-line) 
Table 7: General GHPs - GMPs per stage.

\begin{tabular}{|c|c|}
\hline $\begin{array}{l}\text { Stage of the flow chart } \\
\text { (Fig.1) }\end{array}$ & $\begin{array}{c}\text { Good Hygiene Practices - Good Manufacturing } \\
\text { Practices }\end{array}$ \\
\hline Receipt/storage of olives & $\begin{array}{l}\text { The receipt of the olives must be done in a roofed } \\
\text { place. The olives must not come into contact with } \\
\text { the olive oil. Storage that is being used for diesel } \\
\text { and pesticides must not be used for olives because } \\
\text { the smell will go to the olive oil. }\end{array}$ \\
\hline $\begin{array}{l}\text { Transfer the olives to the } \\
\text { leaf remover. Check the } \\
\text { olives for foreign objects }\end{array}$ & $\begin{array}{l}\text { Remove as much of the leaves and foreign objects } \\
\text { as possible because they give a sour taste to the } \\
\text { olive oil. }\end{array}$ \\
\hline Washing the olives & $\begin{array}{l}\text { Microbiological testing of the water that is used in } \\
\text { the equipment for washing the olives. }\end{array}$ \\
\hline Breaking the fruit & Good maintenance of the equipment. \\
\hline Milling of the fruit & $\begin{array}{l}\text { Good maintenance of the equipment. The milling } \\
\text { lasts about } 10-30 \text { seconds, depending on the } \\
\text { olives. }\end{array}$ \\
\hline Kneading of the fruit & $\begin{array}{l}\text { Good maintenance of the equipment. The } \\
\text { kneading lasts about } 35-50 \text { minutes, depending on } \\
\text { the olives. }\end{array}$ \\
\hline $\begin{array}{l}\text { The olive paste goes to } \\
\text { the centrifuge }\end{array}$ & $\begin{array}{l}\text { Water temperature must be } 30^{\circ} \mathrm{C} \text {. The cleaning of } \\
\text { the centrifuge must be done twice a week for the } \\
\text { manual and every day for the single type of } \\
\text { centrifuge. The temperature of olive presses that } \\
\text { use centrifugal force must not exist } 30^{\circ} \pm 3^{\circ} \mathrm{C} \text {. }\end{array}$ \\
\hline Filtration of the olive oil & $\begin{array}{l}\text { The filters must be cleaned according to the } \\
\text { cleaning program. The filters must be cleaned } \\
\text { when necessary. }\end{array}$ \\
\hline $\begin{array}{c}\text { Final filtration of the } \\
\text { olive oil }\end{array}$ & $\begin{array}{l}\text { The filters must be cleaned according to the } \\
\text { cleaning program. The filters must be cleaned } \\
\text { when necessary. The second filters are cleaned } \\
\text { automatically twice a day and every } 15 \text { days are } \\
\text { disassembled and cleaned more thoroughly. }\end{array}$ \\
\hline $\begin{array}{l}\text { Place the olive oil into } \\
\text { the clients' pots }\end{array}$ & $\begin{array}{l}\text { The pots must be checked before they are used. } \\
\text { The pots must be suitable for olive oil. }\end{array}$ \\
\hline Storage & $\begin{array}{l}\text { The olive oil must be in a store room with a } \\
\text { temperature of } 10-15^{\circ} \mathrm{C} \text {, no humidity and no light. } \\
\text { The olives must be in pots with as little air as } \\
\text { possible. No use of pots made of metals such as } \\
\text { iron, nickel, copper etc. No use of light lamps } \\
\text { because the olive tangs. }\end{array}$ \\
\hline Receiv & $\begin{array}{l}\text { The clients' pots must be cleaned and be without } \\
\text { any smell. }\end{array}$ \\
\hline
\end{tabular}




\subsection{GHPs - GMPs}

Table 7 presents all the stages of the GMP and GHP in order to avoid contamination. In addition to the most significant factors and the relative required controls involved with CCPs, the rest of the factors in those stages must be controlled in order to assure the purpose of the quality and safety. Such controls usually are prerequisite meters, which are grouped and organized by means of hygiene practices. The processes of Olive Oil Industries include stages that are not under the Industry responsibilities. All the requirements related to hygiene practice during the industry operation either refer to equipment maintenance or to cleaning/disinfection procedure of equipment and the practice for foreign matters must be included in the prerequisite programs (PRPs).

\section{Conclusions}

The detailed analysis of the safety and hygienic factors affecting the quality and safety of the whole process of the examined delicatessen products (sausages, ham, bacon, lountza, hiromeri) approved that the controls of CCPs relative to the raw material specification, the temperature in the retaining and thermal processing steps, as well as the PRPs relative to the hygienic conditions during production should be satisfied.

\section{References}

[1] Codex Alimentarius CAC/RCP 1(1999). Recommended International Code of Practice General Principles of Food Hygiene. CAC/RCP 1-1969, Rev. 3-1997, Amd. (1999).

[2] Tzia, C., \& Tsiapouris, A. (1996). Application of the hazard analysis critical control point (HACCP) system in the food industry (pp. 17-32). Athens: Papasotiriou.

[3] Notermans, S., Zwietering, M., \& Mead, G. (1994). The HACCP concept: Identification of potentially hazardous micro-organism. Food Microbiology, 11, 203-214.

[4] Panisello, P., Rooney, R., Quantick, P. C., \& Stanwell-Smith, R. (2000). Application of foodborne disease outbreak data in the development and maintenance of HACCP systems. International Journal of Food Micro, 59, 221-234.

[5] Christaki, T., \& Tzia, C. (2003). Quality and safety assurance in winemaking. Food Control, 13, 503-517.

[6] Ropkins, K., \& Beck, A.J. (2000). Evaluation of worldwide approaches to the use of HACCP to control food safety. Trends in Food Science and Technology, 11, 10-21.

[7] Conter, M., Zanardi, E., Ghidini, S., Pennisi, L., Vergara, A., Campanini, G. \& Ianieri, A. (2007). Survey on typology, PRPs and HACCP plan in dry fermented sausage sector of Northern Italy. Food Control, 18, 650-655. 
[8] Panisello, P.J., \& Quantick, P.C. (2001). Technical barriers to hazard analysis critical control point (HACCP). Food Control, 12, 165-173.

[9] Codex Alimentarius Commissions (2002). Proposed draft principles and guidelines for the conduct of microbiological risk management (at step 3 of the procedure). CX/FH 03/7. Joint FAO/WHO Food Standards Programme.

[10] Grill, C.O., \& Molin, G. (1991). Modified atmosphere and vacuum packaging. In N. J. Russell \& G.W. Gould (Eds.), Food preservatives (pp. 172-199). Glasgow: Blackie.

[11] J. Metaxopoulos, D. Kritikos, E.H Drosinos. 2003. Examination of microbiological parameters relevant to the implementation of GHP and HACCP system in Greek meat industry in the production of cooked sausages and cooked cured meat products, Food Control, 14, 323-332. 